\title{
Liberalism with a Vengeance?: Three New Books on Social Policy in New Zealand
}

\author{
Edward Dickinson
}

- David Thomson, A World Without Welfare: New Zealand's Colonial Experiment (Auckland: University Press/Bridget Williams Books, 1998)

- Margaret McClure, A Civilised Community: A History of Social Security in New Zealand 1898-1998 (Auckland: Auckland University Press/Historical Branch, Department of Internal Affairs, 1998)

- Bronwyn Dalley, Family Matters: Child Welfare in Twentieth-Century New Zealand (Auckland: Auckland University Press/Historical Branch, Department of Internal Affairs, 1998)

Two of these books were commissioned by the New Zealand Department of Social Welfare to mark the centennial anniversary of the introduction of old-age pensions in 1898. But of course all three studies are also part of the avalanche of historical literature on the development of social policy around the world that has been generated by the world-wide fiscal crisis of social policy and the New Right assault on the welfare state. All three are part of the attempt to come to terms with what has happened to the postwar vision of the welfare state. Taken together, and building on the work of Margaret Tennant, Francis Castles, Linda Bryder, and others, they paint a striking and conceptually coherent picture of the grand trajectory of change over social policy in the past century.

David Thomson's slim, focused study of provision for old age before the emergence of the welfare state sets the scene with admirable economy and clarity. In the opening pages of the book, Thomson accuses New Zealand historians of having too neatly organised their narratives of the nation's history around the pre-history of the welfare state; what could not be fitted into that pattern was 'ignored or dismissed as fading remnants of a passing, cruder, less generous society than our own.' His own book, in contrast, is a pre-history of the leaner, meaner New Zealand of the 1990s. Colonial New Zealand, he argues, was a kind of social laboratory for anti-welfare liberalism. The colonial state founded its early social policy on the ideal of self-reliance, and on an abhorrence of dependence on the public purse. Repeated revisions of the law on destitute persons extended the obligation to support the needy to an ever wider circle of relatives. To help those without family, the state encouraged private philanthropy, or subsidised local relief agencies; the state itself gave assistance to the needy only reluctantly, through hospitals and charitable aid

Kōtare 2, no. 2 (1999), pp. 48-56. 
boards; it recognised no right to assistance, and much of public aid was delivered in institutions designed to be a less attractive alternative to poorly paid employment.

The colonial state was anything but a night-watchman state, however; for it pursued remarkably activist policies designed to help citizens achieve selfsufficiency. Above all, it fostered landownership with a kind of crusading zeal, virtually giving enormous amounts of land to an astonishing number of people. Failing that, it often provided work for its citizens-in the civil service, but also in the form of ongoing infrastructure projects, or of outright relief-work. About ten percent of the labour force was on the public payroll. Pensions for civil servants, moreover, appear to have been quite generous-amounting to at least as much as all charitable aid. Finally, immigration controls were intended partly to maintain wage-levels.

The colonists were thus encouraged and obliged to rely on their own resources in avoiding old-age poverty; and in doing so they showed a marked preference for individualist rather than collective strategies. By far the most important strategy they adopted was the acquisition of property in land. The accumulation of private savings was probably the second most popular approach. Life-insurance, private pensions, and friendly societies came a distant third. Thomson suggests that private philanthropy, neighbours, and even family members were not particularly significant sources of income for the elderly.

Thomson explains this pattern essentially as a product of ideology: New Zealand was settled, he argues, during precisely that period when the liberal assault on 'traditional' forms of social assistance and solidarity was at its most intense in Britain. But the new colony was also an ideal setting in which to put liberal social theory into practice: the population was heavily skewed toward the young, able-bodied, and male; there were no existing institutions to be dismantled, as there were in Britain; and the colonial government and settlers were able to seize an enormous amount of land. Not surprisingly, the sudden abandonment of.the 'New Zealand experiment' in liberal social policy at the end of the nineteenth century appears here as a product of changing values, and of changing circumstances. The number of old people in the colony increased by a factor of eight between 1871 and 1901; the declining birth-rate encouraged policies aimed less at parsimony and more at maintaining numbers; the economic uncertainties of the 1870s and 1880s undermined liberal ideas.

A World Without Welfareis an elegant book. Thomson's prose is delightfully clear and economical, his use of statistics convincing and judicious. After setting the scene in an introductory narrative chapter, Thomson presents a systematic, 
focused, chapter-by-chapter examination of different forms of old-age provision. The whole has a gratifying clarity and coherence. Unfortunately, this admirable focus is purchased at the price of some omissions that many readers will no doubt find more than annoying. Thomson is very aware throughout of the masculine bias of the New Zealand 'experiment'; but the implications of this bias remain for the most part unexplored here. Perhaps even more important, the place of Maori in colonial society is virtually ignored. It hardly seems necessary to point out that both public policy and individual colonists' financial strategies were predicated on the transfer of vast amounts of land from Maori to pakeha owners, and that in this sense the colonial state can hardly be said to have fostered 'self reliance' among Maori. To be fair, Thomson makes it clear at the outset that his book will examine only the situation of pakeha working men. Maori, he remarks, 'had a quite separate history in these matters which will require a study of its own.' The obvious question is whether an approach that separates these two histories can give us a viable understanding of colonial social policy or of its social and economic context.

Margaret McClure's A Civilised Community picks up precisely where Thomson leaves off, both chronologically and conceptually. McClure's is both a bigger and a narrower book. Where Thomson treats a broad range of policy and private behavior, McClure focuses almost exclusively on social security programmes administered by the Department of Social Welfare. McClure discusses these programmes in far greater depth and detail than Thomson can give his subject, however; and her study is enriched by her careful attention to race and gender. Indeed, this book has an empirical density and a conceptual complexity that makes it impossible to summarize briefly. It has a strong narrative structure, and follows the development of social security programmes through several epochal changes; but it also sustains discussion of a number of important themes across several chapters and periods, giving the whole a thematic and analytical unity. Finally, McClure consistently enriches her discussion with a wealth of telling examples, revealing anecdotes, and often quite striking quotations, effectively capturing some of the quality of the experiences of people who came into contact with social security programmes.

This is a rich agenda, and in places McClure struggles to maintain a balance between narrative and the pursuit of central analytical themes. Inevitably, moreover, given the scope of the author's task, some subjects are underdeveloped-the intellectual background and motivations of policy; the connection between developments in social security and in politics and in social policy more broadly; statistical analysis of the impact of programmes; international comparisons; the activities of other government departments.

Kōtare 2, no. 2 (1999), pp. 48-56. 
Nevertheless, for the most part McClure manages her material well, presenting a complex and yet surprisingly coherent story that neither beats the reader over the head with a theoretical framework nor loses its way in aimless recounting of developments.

'Community' is an important word for McClure, and the heroes of her book are clearly Michael Joseph Savage and other Labour leaders of the 1930s, who put the idea of universal benefits and the understanding that freedom from want is the precondition for all other freedoms at the heart of New Zealand's social security policy. The Royal Commission of Inquiry into Social Security in 1972, which proposed ensuring the capacity of every citizen to 'belong and participate' in a shared culture and community, comes a close second. As she points out in her introduction, however, social security provisions have not only 'symbolised the country's dominant vision of community' but also 'hinted at important divisions within the nation'; and in fact, much of this book is a sorry tale of conflict, competition, discrimination, and exclusion. Like Thomson, McClure points out the recurring emphasis in government policy on self-reliance-from the crude denunciation of the fecklessness and inferior character of the poor expressed by the administrators of the Charitable Aid system in the 1880s and 1890s, to the complacent neglect or psychologising stigmatisation of the poor in the prosperous 1950s and 1960s, through to calls for the renewal of the work ethic, of the family, and of a sense of individual responsibility in the 1980s and 1990s. She makes it clear, too, that a decidedly masculine bias and the determination to maintain a traditional, male-head-of-household family structure has been central to this conception of 'self -reliance from the outset. Widows, deserted wives, and single mothers have faced fairly consistent discrimination in social security policy. (The introduction of the DPB in 1973 was a major departure from this tradition; but the immediate and massive backlash against that programme makes it clear that it is far from dead.) The ideal of self-reliance was also an important part of the justification for the quite striking tradition of discrimination against Maori, whose family structures and patterns of common ownership, legislators and particularly administrators argued, made them either less needy or simply less worthy of assistance. At least until the end of World War II, Maori were consistently given significantly lower benefits than pakehawhere they were not excluded entirely (as were 'Asiatics', until the 1930s). The competition for benefits between the young and the old, finally, becomes an increasingly central theme in this book. Indeed, the villains of the piece are clearly Robert Muldoon and the elderly. The generous superannuation scheme introduced by the new National government in 1976 constituted a 'seizure of wealth' by the elderly, and it was defended throughout the 1980 s by a 'wary and

Kōtare 2, no. 2 (1999), pp. 48-56. 
powerful' bloc of older voters, stymying any rational social-policy response to the economic problems of the decade.

The broad retrenchment undertaken by New Zealand governments in the 1980s and 1990s appears in McClure's account almost to be an unavoidable consequence of the exacerbation of such divisions in the chilly fiscal climate of the 1970s. By the middle of the 1980s both women on the DPB and the elderly beneficiaries of National's superannuation scheme were increasingly resented by working people struggling to get by; and with unemployment high, the illegitimacy rate passing $20 \%$, and the population aging, the budgetary walls were clearly closing in. McClure implies that the more inclusive and generous recommendations of a second Royal Commission in 1988 were simply unrealistic. In the final sentence of $\underline{A}$ World Without WelfareDavid Thomson suggests that 'there is much to be learned by considering carefully the last time the "new" ideas of the 1990s were dominant'; McClure's account of the 1980s and 1990s leaves one almost believing that the lesson is that sometimes fiscal discipline unavoidably takes priority over social inclusion.

At 365 pages, Bronwyn Dalley's Family Mattersis the longest of these books; and it is a veritable mine of information, presenting detailed and judicious discussions of an extraordinary range of programmes and policies implemented by the Child Welfare Division. Even more than McClure, Dalley makes effective use of quotations, cases, and anecdotes, and in some passages this is a gripping and moving book. At times, the thread of Dalley's narrative threatens to get lost in the thicket of detail; the reader of a book this long needs more clear interpretive signposts. Nevertheless, Family Matterspresents a coherent story. Indeed, if this book is "messier" than McClure's in its presentation of a sometimes overwhelming volume of empirical detail, it also presents a neater narrative. In its broad outlines the trajectory of child welfare policy seems to be simpler than of social security.

Dalley's account is framed by two waves of de-institutionalisation, in the periods 1916-1921 and 1989-1993. In between, there is a massive growth of institutional care: the number of children in institutions tripled between 1948 and 1972. In a sense, we are in familiar territory here: in McClure's account, too, the 1950s saw a return to traditions and principles similar to those of the late nineteenth and early twentieth centuries. While the relative social and economic significance of social security programmes seems to have been fairly sensitive to economic change, however, before the late 1980s the pattern in child welfare appears to have been simpler: steady growth. The Child Welfare Division (in its various organisational incarnations) had 20 child welfare officers in the 1920s, 100 in the mid-'40s, 291 in 1971; there were some 2,000 children in contact with

Kōtare 2, no. 2 (1999), pp. 48-56. 
public programmes in $1900 ; 7,000$ in $1925 ; 16,000$ in 1971 . There was an almost equally steady evolution toward a focus on prevention, rather than intervention; toward the 'rehabilitation' of the family as the ultimate aim of child welfare policy; and toward psychological explanations and therapies for the problems of children and families. Finally, the expansion of child welfare services seems to have been predicated partly on a growing willingness to rely on volunteers, private organisations, and families themselves. In the early part of this century the personnel of the Child Welfare Division looked on poor families and especially private organisations with ill-disguised suspicion; by the 1980s 'achieving a "mixed economy" of welfare, involving families, the community, and the state ... , had finally become official policy.' In sum, public child welfare programmes became more pervasive, less coercive, more responsive to the needs of families and children, and more inclusive with respect to private initiative. This is a pattern that will be familiar to students of child welfare in other western countries.

And yet, the story of child welfare policy in New Zealand as told here is hardly a success story. Much as the retrenchment in social security in the 1980s and 1990s appears in McClure's book as a product of the fiscal problems created in the 1970s, the sudden transformation of child welfare programmes at the end of the 1980s appears in Dalley's as the product of a long-term crisis that can be traced back to the 1960s. Expanding case-loads were the product not of success but of 'social breakdown'; and in the 1970s and 1980s the child welfare system could not keep up with the skyrocketing number of cases. After 1982, for example, reports by social workers on young people brought before the juvenile courts were no longer mandatory; the Division had to open a rapidly growing number of 'family homes'; its staff increasingly felt powerless and overwhelmed; its institutions were increasingly unable to handle the 'more violent, difficult and severely traumatised residents' entering them.

Dalley characterises the Children, Young Persons, and Their Families Act 1989 as a remarkably progressive and effective piece of legislation, a model for other countries; and she makes a strong case for regarding the Act as the culmination of long-term developments. Social workers were now to 'play the role of assistant, facilitator or coordinator' and to avoid 'disruptions to families'; the Act abandoned the 'welfare approach' to juvenile delinquency as 'intrusive and coercive', prefering to make young people' accountable for their offending' and to replace juvenile court proceedings with family group conferences; it closed institutions and offered home help, parenting classes, and recreation programmes instead; resources were shifted to subsidising private groups, rather than funding public programmes. And yet, as David Thomson might point

Kōtare 2, no. 2 (1999), pp. 48-56. 
out, the ideas on which the new approach was founded echo the terms of the liberal world-view of the nineteenth century: it aimed to reduce costs by passing responsibility for maintaining social order back to the family, reduce state involvement in social relations, foster individuals' sense of their own responsibility for their fate, support charity rather than create entitlement. Equally important, the broader context Dalley describes makes the Act almost appear to be the product of exhaustion, rather than of a new faith in people and their families. In fact, the book closes on a note of ambivalence; Dalley seems to imply that the new, family-friendly approach might degenerate, under fiscal pressure, into an abrogation of public responsibility.

At the same time, Dalley appears to be uncertain whether nineteenthcentury values can provide solutions to twenty-first century problems. The 'rediscovery' of child abuse in the 1980s and 1990s is a good example: there were 2,131 child abuse and neglect investigations in 1987/1988, and almost 11,000 in 1992. An obvious question is whether a society that puts a high value on children's rights and welfare actually can get out of the business of policing families. In this respect the concluding sections of Family Mattersecho those of McClure's A Civilised Community; for McClure, too, points out that as of 1993 , the drop in the numbers of unemployed was being matched by a rise in the numbers on the DPB and on sickness and invalids' benefits, and that there had been 'few gains overall in reducing benefit costs.' In the concluding paragraph of A World Without Welfare, David Thomson suggests that social policy has been characterised by 'a long pattern of cyclical swings between greater individual and family responsibility and greater welfare action.' After reading McClure's and Dalley's account of the exhaustion of the welfare state in the 1970s and 1980s, one is almost inclined to take heart from this perspective. It might be better to drive in circles than to arrive at a dead end.

Kōtare 2, no. 2 (1999), pp. 48-56. 